\title{
ON A NEW SPECIES OF FRESHWATER CRAB OF THE GENUS JOHORA (BRACHYURA, POTAMIDAE) FROM PENINSULAR THAILAND
}

\author{
BY
}

PIMONPAN LEELAWATHANAGOON ${ }^{1}$ ), VACHIRA LHEKNIM ${ }^{1}$ ) and PETER K. L. NG ${ }^{2,3}$ )

1) Department of Biology, Prince of Songkla University, P.O. Box 3 Ko Hong, Songkhla 90112, Thailand

2 ) Department of Biological Sciences, National University of Singapore, Lower Kent Ridge Road, Singapore 119260, Republic of Singapore

\begin{abstract}
A new species of freshwater potamid crab of the genus Johora Bott, 1966, previously known only from Peninsular Malaysia and Singapore, is described from southern Thailand. The new species, $J$. thaiana, can be distinguished from congeners by its setose terminal segment of the male first pleopod, which is distinctly tapering and forming a conical structure, with the distal part slightly curved outwards.
\end{abstract}

\section{RÉSUMÉ}

Une espèce nouvelle de crabe Potamidae d'eaux douces du genre Johora Bott, 1966, connu auparavant seulement de la péninsule malaise et de Singapour, est décrite du sud de la Thaïlande. La nouvelle espèce, J. thaiana, peut être distinguée de ses congénères par le segment terminal sétifère du premier pléopode mâle, qui est distinctement effilé et forme une structure conique, avec la partie distale légèrement recourbée vers l'extérieur.

\section{INTRODUCTION}

While studying the freshwater fauna collected from the eastern river basin of Peninsular Thailand, the authors examined four lots of crab specimens collected from streams in the upper watershed of the Kolok River Basin and two from streams in the upper watershed of the Sai Buri River Basin that could not be referred to any known species. These specimens are here regarded as a new species of Johora Bott, 1966, subfamily Potaminae Ortmann, 1896, family Potamidae Ortmann, 1896 (sensu Yeo \& Ng, 2004). Bott (1966) established the genus Johora

3 ) e-mail: peterng@nus.edu.sg 
(as a subgenus of Stoliczia Bott, 1966) for species supposedly endemic to the Malay Peninsula, occurring along the central highlands northwards from Singapore into the southern half of Peninsular Malaysia. Ng (1987) subsequently revised Johora and regarded it as a distinct genus. Members of this genus are characterized by a squarish to subrectangular carapace usually covered with numerous short stiff setae, the exopod of the third maxilliped with a long flagellum, the ventral fold of the terminal segment of the male first pleopod is narrow and closely apposed to the dorsal fold, and the groove for the male second pleopod is relatively narrow $(\mathrm{Ng}$, 1987, 1988, 2004).

The present paper describes the first Johora species known from Thailand, bringing the total number in the genus to 15 . Measurements given are of the carapace width and length in millimeters, respectively. The abbreviations G1 and G2 are used for the male first and second pleopods, respectively. Terms used basically follow those utilized by $\mathrm{Ng}$ (1988), while the G1 and G2 terminology is adapted from Brandis et al. (1999). Specimens examined are deposited in the Prince of Songkla University Zoological Collection, Prince of Songkla University, Hat Yai, Thailand (PSUZC) and the Zoological Reference Collection, Raffles Museum of Biodiversity Research, Department of Biological Sciences, National University of Singapore (ZRC).

\section{TAXONOMY}

Family Potamidae

Genus Johora Bott, 1966

Johora thaiana sp. nov. (figs. 1, 2)

Material examined. - Holotype: male (26.1 by $22.0 \mathrm{~mm}$ ), PSUZC 19990714-03-03A, Huai Sam Sop, Ko Lok River Basin, Ban Ba La, $140 \mathrm{~m}$ above sea level, 5.71583 ${ }^{\circ} \mathrm{N} 101.83917^{\circ} \mathrm{E}$, Wang District, Narathiwat Province, coll. V. Lheknim, 14 July 1999. Paratypes: Kolok River Basin, Narathiwat Province: 3 males (10.5 by $9.0 \mathrm{~mm}-27.6$ by $24.7 \mathrm{~mm}$ ) 2 females (16.5 by $14.4 \mathrm{~mm}, 17.7$ by $14.7 \mathrm{~mm}$ ), PSUZC-19990714-03.03, 1 male (22.2 by $18.6 \mathrm{~mm})$, ZRC, same data as holotype. - 1 male (25.1 by 21.8$), 1$ female (24.4 by $19.5 \mathrm{~mm}$ ), PSUZC-19990715-02.03, 1 female $(21.0$ by $17.4 \mathrm{~mm}$ ), ZRC, Sirindthron Waterfall, Ban Ba La, $300 \mathrm{~m}$ above sea level, $5.8^{\circ} \mathrm{N} 101.82083^{\circ} \mathrm{E}$, Wang District, coll. V. Lheknim, 15 July 1999. - 4 males (9.1 by $7.9 \mathrm{~mm}-25.0$ by $21.4 \mathrm{~mm}$ ), 3 females (11.6 by $9.3 \mathrm{~mm}$ - 15.0 by $13.2 \mathrm{~mm}$ ), PSUZC-20020126-01.01, Klong Ai Ka Ding, Ban Bala, $300 \mathrm{~m}$ above sea level, $5.80567^{\circ} \mathrm{N} 101.81167^{\circ} \mathrm{E}$, Wang District, coll. V. Lheknim and P. Leelawathanagoon, 26 January 2002. Sai Buri River Basin, Narathiwat Province: 1 male (13.0 by 11.0 mm), PSUZC-20001008-01.03, Klong Phu Khao Tong, Ban Phu Khao Tong, $400 \mathrm{~m}$ above sea level, $5.8^{\circ} \mathrm{N} 101.77283^{\circ} \mathrm{E}$, Sukirin District, coll. V. Lheknim and P. Leelawathanagoon, 8 October 2000. - 1 female (12.5 by 10.6 mm), PSUZC-20020126-04.06, Klong Phu Khao Tong, Ban Phu Khao Tong, $180 \mathrm{~m}$ above sea level, $5.80133^{\circ} \mathrm{N} 101.7615^{\circ} \mathrm{E}$, Sukirin District, coll. V. Lheknim \& P. Leelawathanagoon, 26 January 2002. 
Non-type material: 1 juvenile (damaged, only chela and carapace remaining), PSUZC-2001120903.04, upper Klong Ai Ka Ding, Ban Bala, $220 \mathrm{~m}$ above sea level, 5.80933 ${ }^{\circ} \mathrm{N} 101.82283^{\circ} \mathrm{E}$, Wang District, Narathiwat Province, coll. V. Lheknim and P. Leelawathanagoon, 9 December 2001.

Description. - Carapace distinctly broader than long, dorsal surfaces relatively flat, frontal region rugose, covered by small flattened granules lined with very short setae; protogastric and branchial regions almost smooth except for scattered, very short setae, lateral regions with distinct oblique striae, cervical grooves distinct, very broad, shallow, reaching deep H-shaped central depression (figs. 1, 2A). Anterolateral margins arcuate, crested, lined with small blunt granules, appearing gently serrated, clearly separated from distinctly converging posterolateral margins. Frontal margin gently deflexed, straight, not clearly separated from supra-orbital margin, epibranchial tooth distinct, clearly separated from anterolateral margin by deep, V-shaped notch, external orbital angle broadly triangular, appearing truncate, outer margin gently convex, gently serrated, twice as long as inner margin. Epigastric cristae very prominent, rugose, not sharp; postorbital cristae strong, sharp; epigastric cristae distinctly anterior to postorbital cristae and separated from postorbital cristae by distinct oblique groove. Orbits large, eyes well developed, corneal pigmentation well developed, distinct. Sub-orbital, sub-branchial, and pterygostomial regions rugose. Outer surfaces of epistome (between anterior and posterior margins) and pterygostomial regions moderately hirsute. Median triangle on posterior margin of epistome with sharp tip, sides of triangle gently concave, lateral parts of epistomal margins appear truncate, neither sinuous nor triangular, margin bordering efferent opening gently concave. Mandibular palp simple, terminal segment single-lobed. Third maxillipeds quadrate, ischial groove median, moderately setose, with scattered stiff setae on outer surfaces of exopod and between ischial sulcus and outer margin, inner cutting margins and outer surfaces of meri reaching to bases; ischial sulcus deep, distinct (fig. 2B). Exopod with distinct flagellum, reaching across width of merus.

Chelipeds unequal, right usually slightly larger, fingers of both chelae distinctly longer than palm, tips brown. Outer surfaces of all segments rugose. Carpus with long, sharp spine on inner angle. Inner margins of cheliped merus and basisischium covered with scattered, stiff setae.

Ambulatory legs relatively long, second leg longest, surfaces of all segments rugose, dorsal margin gently serrated. Dactylus of first three pairs long, last leg shortest. Lower margin of first ambulatory merus, propodus, and dactylus (especially propodus) lined with dense, short stiff setae, propodus and dactylus of other legs with scarce stiff setae.

First two thoracic sternites with surfaces moderately hirsute, especially suture between sternites 1 and 2. Male abdomen triangular, reaching imaginary transverse 
(A)

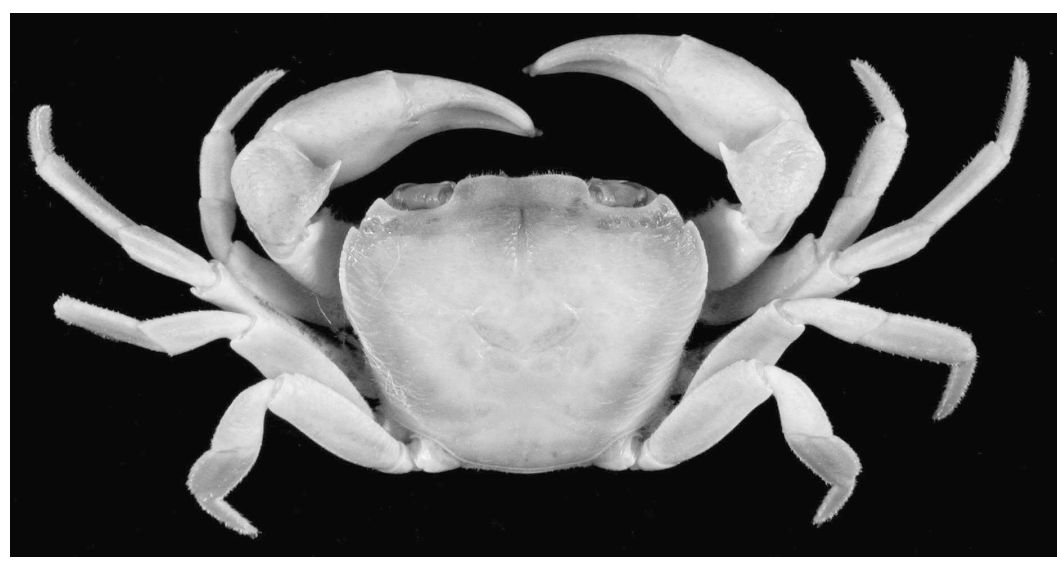

(B)

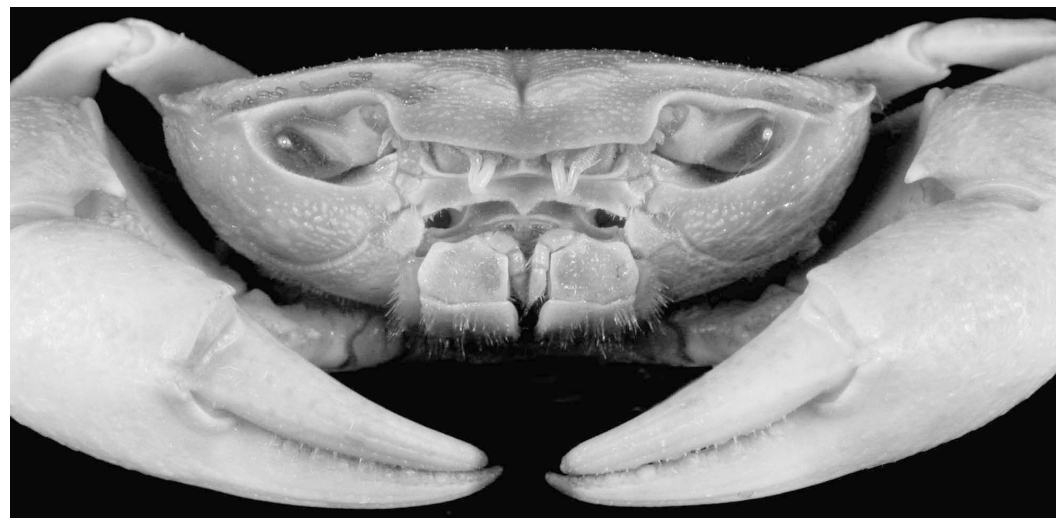

(C)

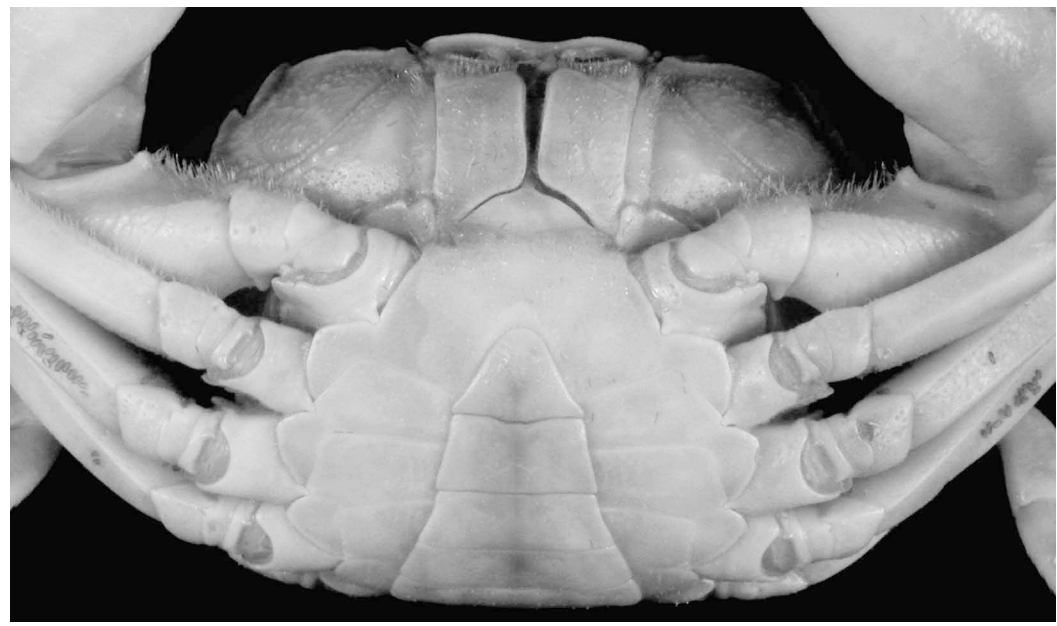

Fig. 1. Johora thaiana sp. nov. Holotype male, PSUZC 19990714-03-03A, 26.1 by $22.0 \mathrm{~mm}$. A, overall view; B, frontal view; C, ventral view of carapace. 

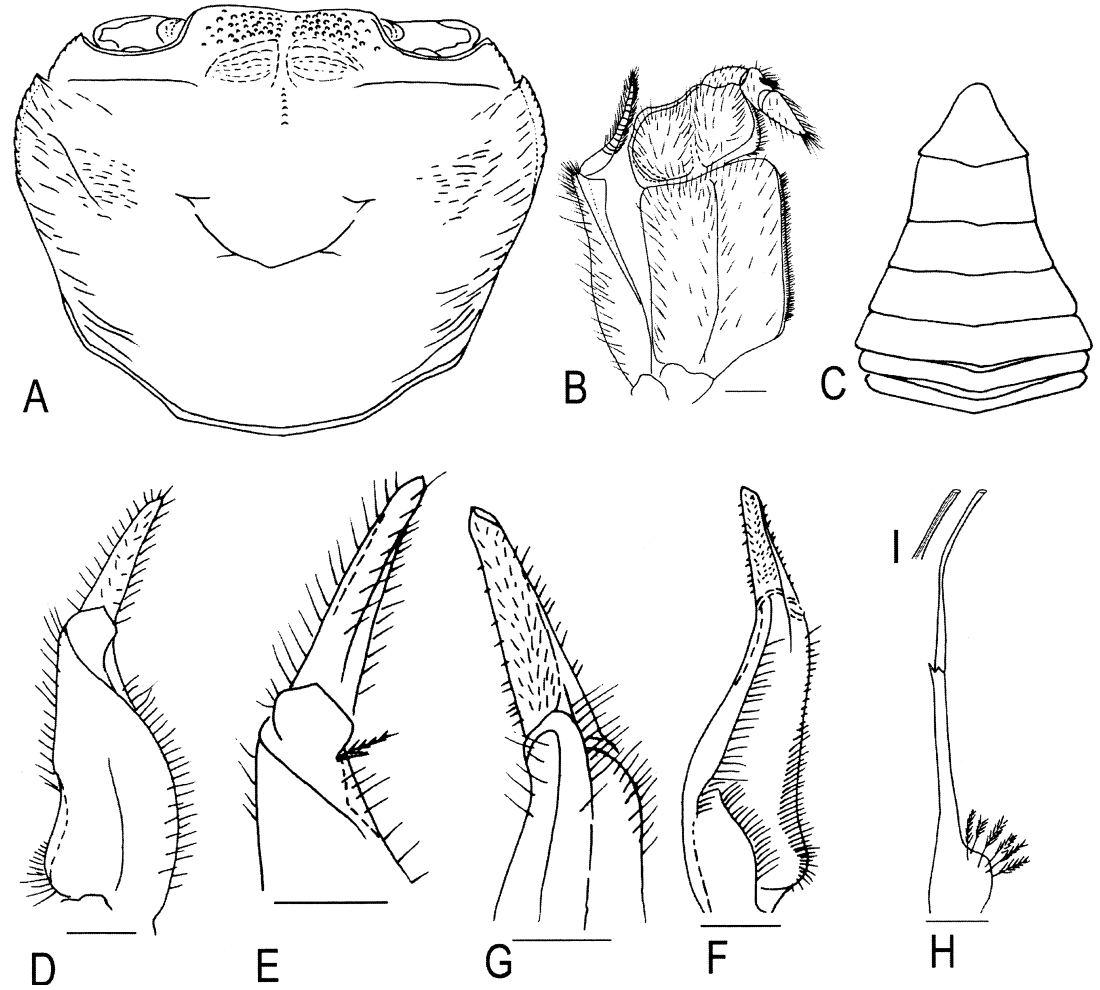

Fig. 2. Johora thaiana sp. nov. Holotype male, PSUZC 19990714-03-03A, 26.1 by $22.0 \mathrm{~mm}$. A, carapace; B, right third maxilliped; C, abdomen; D-G, right G1; H, right G2; I, tip of distal part of right G2. E, G, G1 terminal segment; D, E, dorsal view; F, G, ventral view. Scales = $1.0 \mathrm{~mm}$.

line connecting posterior edges of bases of chelipeds; first segment reaching base of coxa of last pair of ambulatory legs; second and third segments broadest; first to sixth segments progressively more trapezoidal; lateral margins of segment 6 straight or slightly concave; telson longer than segment 6 , distinctly triangular, lateral margins concave, tip rounded (fig. 2C). Mature female paratypes with well developed rounded abdomen, covering most of thoracic sternum.

Male gonopores coxal. G1 moderately elongate with distal end slightly curved outwards, terminal and subterminal segments clearly demarcated, subterminal segment slightly sinuous, with broad cleft on outer distal border; terminal segment almost straight, elongate, conical, c. 0.4 times length of subterminal segment, tip rounded (fig. 2D-G). G1 terminal segment usually covered with scattered stiff setae. G2 subequal in length to G1, tip with prominent spoon-like structure and elongated sclerotized tube (= flagellum) (fig. $2 \mathrm{H}, \mathrm{I}$ ), c. 0.65 times length of basal segment. 
Colour. - In life, the animals are dorsally a dull brown with the ventral surfaces dirty white to pale orange without any distinct colour pattern. The fingers of the chelipeds are a bright orangish-brown.

Remarks. - The genus Johora Bott, 1966 (type species Potamon (Potamon) johorense Roux, 1936, by original designation; gender feminine), currently contains 14 species, all from Peninsular Malaysia and Singapore, viz. J. aipooae (Ng, 1986), J. counsilmani (Ng, 1985), J. gapensis (Bott, 1966), J. grallator Ng, 1988, J. gua Yeo, 2001, J. hoiseni Ng \& Takeda, 1992, J. johorensis (Roux, 1936), J. intermedia $\mathrm{Ng}, 1986$, J. murphyi $\mathrm{Ng}, 1986$, J. punicea $(\mathrm{Ng}, 1985)$, J. singaporensis (Ng, 1986), J. tahanensis (Bott, 1966), J. thoi $\mathrm{Ng}, 1990$, and J. tiomanensis ( $\mathrm{Ng} \&$ Tan, 1984) (see Yeo et al., 1999; Yeo, 2001; Ng, 2004).

The present new species is the first reported from outside Peninsular Malaysia and Singapore, although its presence in southernmost Thailand is not at all surprising since this area is still geographically part of the Malay Peninsula, south of the narrow Isthmus of Kra $(\mathrm{Ng}, 1988)$. Johora thaiana sp. nov. is most similar to J. tahanensis and J. hoiseni from Pahang and southern Kelantan in Malaysia, respectively. $\mathrm{Ng}$ (1988: 42) referred specimens from Pahang (type locality) and Kelantan to J. tahanensis and figured the G1s of both (Ng, 1988, fig. 18). Ng \& Takeda (1992, figs. 2, 3) subsequently showed that the Kelantan specimens should be referred to a new species, J. hoiseni. From J. tahanensis, J. thaiana can easily be separated by its smaller adult size and the G1 terminal segment being distinctly straighter (vs. curved outwards) (cf. Bott, 1970, pl. 40 fig. 57; Ng, 1988, fig. 18C, F; Ng \& Takeda, 1992, figs. 3B-E). Specimens of J. tahanensis of about $25 \mathrm{~mm}$ in carapace width that we have examined are still juveniles, with males having poorly developed G1s. On the other hand, specimens of $J$. thaiana $25 \mathrm{~mm}$ in carapace width are already fully mature, with well-developed G1s and the female abdomen completely covers the thoracic sternum. The adult size of J. thaiana and J. hoiseni is similar, but the form of their G1s easily separates them. In J. thaiana, the G1 terminal segment is distinctly tapering, forming a conical structure, with the distal part only slightly curved (fig. 2D-G). In J. hoiseni, however, the G1 terminal segment has the lateral margins subparallel or gently converging for much of their length and is straight to gently curving upwards (see $\mathrm{Ng}, 1988$, fig. 18D, E [as J. tahanensis]; Ng \& Takeda, 1992, figs. 3B-E). The G1 terminal segment of $J$. hoiseni is also distinctly more setose compared to that of J. thaiana (fig. 2DG; Ng, 1988, fig. 18E; Ng \& Takeda, 1992, figs. 3C, E). To this effect, we have compared the large series of J. tahanensis and J. hoiseni available in the ZRC (see $\mathrm{Ng} \&$ Takeda, 1992, for list of material) with the good series of J. thaiana at hand. The differences observed are consistent. As such, we are of the opinion that the southern Thai specimens should be referred to a new species. 
The other species allied to J. tahanensis and J. hoiseni is J. thoi, from Terengganu in northeastern Peninsular Malaysia, but although their carapaces are superficially similar, the G1 terminal segment of $J$. thoi is substantially longer than that of any of the other species discussed here (see $\mathrm{Ng}, 1990$, fig. 2).

Etymology. - The specific name is derived from "Thailand," alluding to the fact that this is the first Johora species discovered in Thailand. The name consequently is an adjective, agreeing in gender with the (feminine) generic name.

Habitat. - This species appears to be wholly aquatic, being found under rocks and vegetation, especially by the side of the main stream and in adjacent pools. It is more common in shaded areas and where the water flow tends to be slower. It is most common in the upper stretches of hill streams: the types were obtained from streams located in an area higher than $200 \mathrm{~m}$ above sea level. They are nocturnal, and in the day they spend most of their time hiding beneath rocks or among clumps of leaves and detritus.

Sympatric decapod taxa collected with J. thaiana are the frewhwater crabs, Parathelphusa maculata De Man, 1879, Phricotelphusa sp., and Stoliczia panhai $\mathrm{Ng} \&$ Naiyanetr, 1986 [in Ng, 1986b]; and the freshwater prawns Macrobrachium forcipatum $\mathrm{Ng}, 1995$, and M. neglectum (De Man, 1905).

Distribution. - So far only known from the type locality in the upper watershed areas of the Kolok and Sai Buri River Basins in the Wang and Sukirin District, respectively, in Narathiwat Province, southern Thailand.

\section{ACKNOWLEDGEMENTS}

This study has been supported by grant Sci-Gen/44/3-4 to the first author from the Faculty of Science, Prince of Songkla University. We would like to thank Dr. Darren C. J. Yeo (ZRC) for his help during the study. We are thankful to Dr. Harold K. Voris and Jeniffer Mui, The Field Museum of Natural History (FMNH), Chicago, for reading and correcting the manuscript. This is the Prince of Songkla University Zoological Collection Contribution No. 6.

\section{REFERENCES}

Botт, R., 1966. Potamiden aus Asien (Potamon Savigny and Potamiscus Alcock) (Crustacea, Decapoda). Senckenbergiana biol., 47: 469-509.

— —, 1970. Die Süsswasserkrabben von Europa, Asien, Australien und ihre Stammesgeschichte. Eine Revision der Potamoidea und Parathelphusoidea (Crustacea, Decapoda). Abhand. Senckenberg. naturforsch. Ges., 526: 1-338, pls. 1-58.

BRAndis, D., V. STORCH \& M. TÜRKAY, 1999. Morphology and function of the copulatory system in freshwater crabs of the genus Potamon. Journ. Morphol., 239: 157-166. 
MAN, J. G. DE, 1879. On some new and imperfectly known podophthalmous Crustacea of the Leyden museum. Notes Leyden Mus., 1: 53-73.

— _ 1905. Synonymical remarks about Palaemon neglectum nov. nom. and Palaemon reunionensis Hoff. Notes Leyden Mus., 26: 201-206, pl. 15.

NAIYANETR, P., 1978. The geographic distribution of freshwater crabs in Thailand. Geogr. Journ. geogr. Ass. Thailand, 3 (3): 24-43.

— _ 1988. Freshwater crabs in Thailand. In: Book published in memory of the Royal Cremation of associate professor Dr. Praphun Chitachumnong, Mahidol University 15 pp., 8 col. pls. (Phaisalsilpa Press, Bangkok).

NG, P. K. L., 1985. Freshwater decapod crustaceans from Pulau Tioman, West Malaysia. Zool. Meded., Leiden, 59: 149-162.

- - 1986a. Terrapotamon gen. nov., a new genus of freshwater crabs from Malaysia and Thailand, with description of a new species, Terrapotamon aipooae gen. et sp. nov. (Crustacea: Decapoda: Brachyura: Potamidae). Journ. nat. Hist., London, 20: 445-451.

_ _ 1986b. Preliminary descriptions of 17 new freshwater crabs of the genera Geosesarma, Parathelphusa, Johora and Stoliczia (Crustacea Decapoda, Brachyura) from South East Asia. Journ. Singapore natn. Acad. Sci., 15: 36-44.

_ _ 1987. A revision of the Malayan freshwater crabs of the genus Johora Bott, 1966 (Decapoda: Brachyura: Potamidae). Malayan Nat. Journ., Kuala Lumpur, 41: 13-44.

_ _ 1988. The freshwater crabs of Peninsular Malaysia and Singapore: i-viii, 1-156, figs. 163, 4 col. pls. (Department of Zoology, National University of Singapore; Shinglee Press, Singapore).

— - 1990. A new species of Johora Bott, 1966 (Crustacea: Decapoda: Brachyura: Potamidae) from Pulau Redang, Trengganu, Peninsular Malaysia. Journ. nat. Hist., London, 24: 305-310.

— _ 1995. Freshwater decapod crustaceans (Potamidae, Palaemonidae) of Temengor Forest Reserve, Hulu Perak, Malaysia. Malayan Nat. Journ., Kuala Lumpur, 48: 249-257.

— _, 2004. Crustacea: Decapoda, Brachyura. In: C. Yule \& H. S. Yong (eds,), The freshwater invertebrates of Malaysia and Singapore: 311-336. (Malaysian Academy of Sciences, Kuala Lumpur).

NG, P. K. L. \& P. NAIYANETR, 1993. New and recently described freshwater crabs (Crustacea: Decapoda: Brachyura: Potamidae, Gecarcinucidae and Parathelphusidae) from Thailand. Zool. Verh., Leiden, 284: 1-117, figs. 1-68.

NG, P. K. L. \& M. TAKEDA, 1992. On some freshwater crabs (Crustacea: Brachyura: Potamidae, Parathelphusidae and Grapsidae) from Peninsular Malaysia. Bull. nat. Sci. Mus., Tokyo, (A, Zool.) 18: 103-116.

NG, P. K. L. \& L. W. H. TAN, 1984. A new freshwater crab, Stoliczia (Johora) tiomanensis n. sp. (Decapoda: Brachyura: Potamidae) from Palau Tioman, West Malaysia. Malayan Nat. Journ., Kuala Lumpur, 37: 167-174.

Roux, J., 1936. Second note upon freshwater decapod crustaceans from the Malay Peninsula. Bull. Raffles Mus., Singapore, 12: 29-33, pls. 12-13.

YEO, D. C. J., 2001. A new cavernicolous species of freshwater crab (Crustacea: Brachyura: Potamidae) from Palau Tioman, Peninsular Malaysia. Proc. biol. Soc. Washington, 114: 618623.

YeO, D. C. J., Y. X. CAI \& P. K. L. NG, 1999. The freshwater and terrestrial decapod Crustacea of Palau Tioman, Peninsular Malaysia. Raffles Bull. Zool., (Suppl.) 6: 197-244.

YeO, D.C. J. \& P.K.L. NG, 2004. Recognition of two subfamilies in the Potamidae Ortmann, 1896 (Brachyura, Potamidae) with a note on the genus Potamon Savigny, 1816. Crustaceana, 76 (10): 1219-1235. 